DOI: $10.24014 /$ jdr.v31i2.11087

\title{
IDENTITAS GAYA FESYEN ISLAMI PADA SIVITAS AKADEMIKA DI PERGURUAN TINGGI KOTA SEMARANG
}

\author{
Arni Ernawati $^{1^{*}}$, Erna Zuni Astuti ${ }^{2}$, Teguh Hartono Patriantoro ${ }^{3}$, \\ Rustono Farady Marta ${ }^{4}$, Jouns Candy Felice Lang ${ }^{5}$ \\ ${ }^{1,2,3}$ Universitas Dian Nuswantoro \\ ${ }^{4,5}$ Universitas Bunda Mulia \\ *Email: ernawatiarni@gmail.com
}

\section{Kata kunci}

Sivitas akademika, identitas, fesyen islami, perguruan tinggi

Keywords Scholars, identity, islamic fashion, college

\begin{abstract}
Abstrak
Identitas menjadi penciri setiap individu, terutama bagi para sivitas akademika, baik dosen maupun mahasiswa. Penelitian ini bertujuan untuk menelusuri identitas gaya fesyen islami dalam lingkup pendidikan tinggi di Kota Semarang. Penelitian ini menggunakan pendekatan kualitatif dengan metode studi kasus. Informan penelitian terdiri atas empat orang dosen dan empat orang mahasiswa di kampus swasta dan negeri di Kota Semarang. Temuan penelitian ini menunjukkan bahwa salah satu cara untuk mengekspresikan identitas bagi sivitas akademika muslim yaitu menggunakan busana atau pakaian islami. Busana kini telah melampaui fungsinya untuk melindungi tubuh, melainkan telah menjadi sarana komunikasi yang dapat mengekspresikan identitas diri. Semakin berkembangnya zaman, busana juga memiliki peran yang berubah mengikuti waktu. Kini fesyen islami menjadi kebutuhan bagi sivitas akademika muslim untuk mengikuti tren sekaligus menjaga kehormatan diri dan menutup aurat.
\end{abstract}

\begin{abstract}
Identity characterizes each individual, especially for scholars, both lecturers, and students. This study aims to explore the identity of Islamic fashion styles within the scope of higher education in the city of Semarang. This research uses a qualitative approach with a case study method. The research informants consisted of four lecturers and four students at private and public campuses in the city of Semarang. The findings of this study indicate that one way to express an identity for muslim scholars to use islamic clothing or clothing. Clothing has now gone beyond its function to protect the body but has become a means of communication that can express one's identity. With the development of the times, clothing also has a role that changes with time. Now islamic fashion is a necessity for muslim scholars to follow trends while maintaining self-respect and covering their aurat (i.e. body parts required by Islam to be covered).
\end{abstract}

\section{Pendahuluan}

Identitas merupakan sesuatu yang melekat pada diri manusia. Identitas seseorang dapat terbentuk dengan adanya interaksi sosial dengan orang lain yang berada di 
sekitarnya. Faktor sosiallah yang membentuk suatu identitas pada diri seorang manusia. Perwujudan dari tanda suatu identitas dapat berbeda-beda pada seseorang. Bagi perempuan, fesyen dalam berpenampilan sangat penting untuk merepresentasikan identitasnya, sehingga tidak jarang perempuan memandang fesyen sebagai hal yang sangat penting dan bagian yang tidak bisa terpisahkan.

Dalam Islam, fesyen atau gaya berbusana dan berpenampilan memiliki ketentuan tersendiri yang biasa disebut fesyen islami. Salah satunya adalah kaum muslimat diminta untuk mengenakan jilbab atau hijab, karena telah menjadi perintah agama Islam. Oleh sebab itu tidak mengherankan, bila perkembangan tren penggunaan busana muslim (khususnya hijab) di Indonesia kini terlihat sangat signifikan (Hayati et al., 2020).

Tren fesyen islami mulai mengalami perkembangan sejak tahun 2014. Terdapat dua macam perubahan yang signifikan pada nilai dasar pasar menengah konsumen busana muslimat. Pertama, meningkatnya nilai konsep penerapan syariat yang juga akan meningkatkan kesadaran mematuhi syariat. Kedua, saat ini dalam memilih busana para muslimat lebih memilih busana yang dapat menutup aurat sesuai syariat Islam karena semakin rasionalnya para muslimat islami (Dewi \& Puspitasari, 2018). Penelitan Budiyanti (2017) mengungkap di masyarakat masih terdapat keberagaman pengetahuan dan sikap kaum perempuan terhadap hijab.

Penggunaan hijab merupakan hasil sosialisasi yang dialami individu yang di dalamnya terkandung interaksi dengan lingkungan sosialnya (Ramadhini, 2017). Gaya Pemakai busana muslimat saat ini didominasi perempuan muda dengan gaya pakaian yang modis dan up to date. Ini berbeda dengan kondisi awal 1990-an yang jarang ditemui perempuan muda dan remaja putri menggunakan hijab (Ilyas, 2016). Perkembangan tren busana muslim saat ini distimuli oleh semakin maraknya pengguna ponsel pintar yang terhubung dengan beragam media sosial, ditunjang pula berbagai komunitas yang mengedepankan dakwah, kemudian kerap ditemui pula penjualan langsung dalam agenda kegiatan promosi khusus busana muslim yang diselingi peragaan fesyen islami (Dewi \& Puspitasari, 2018).

Kalangan hijaber saat ini menggunakan internet untuk information sharing dan memenuhi kebutuhan informasi untuk berhijab. Terdapat tiga tipe hijaber yaitu hijaber modis, hijaber biasa, hijaber syar'I (Latifah, 2014). Pengalaman sebelumnya yang terjadi pada moslem blogger, motif eksistensi yaitu dengan menggunakan blog berisi konten hijab fesyen karena ingin memperlihatkan dirinya dengan memadupadankan busana muslim dengan tren fesyen dunia melalui blog. Motif penggunaan blog pada moslem blogger yaitu motif atraksi, motif inspirasi, dan motif eksistensi (Istiani, 2015). Akhirnya, ketertarikan pada produk fesyen menjadi tren di kalangan muslimat yang mendorong terjadinya impulse buying dan perilaku itu menjadikan industri fesyen islami berkembang pesat (Febriani \& Purwanto, 2019).

Perkembangan busana muslim juga masuk pada kehidupan pendidikan, terutama pada kalangan dosen dan mahasiswa. Busana menjadi ciri dan identitas sivitas 
akademika muslim dalam mengekspresikan dirinya, salah satunya gaya fesyen islami. Kajian penelitian ini lebih ditujukan pada analisis tren gaya fesyen islami yang sedang berkembang dan digandrungi oleh para anak muda. Tidak terkecuali dosen dan mahasiswa, yang dapat bergaya dengan tetap menutup aurat, bukan berpakaian seksi dan mengumbar aurat. Apalagi, tutorial hijab banyak diedarkan di internet melalui media sosial dan media cetak. Hal itu menjadi rujukan bagi penggunaan hijab dan pakaian modis masa kini (Nisa \& Rudianto, 2017). Penelitian ini bertujuan menelusuri pandangan para pengguna fesyen islami sekaligus melihat geliat identitas sebagai seorang muslim pada keseharian mereka, khususnya di Kota Semarang.

\section{Metode}

Penelitian ini menggunakan pendekatan kualitatif, karena memiliki fleksibilitas yang mampu mengakomordir ragam temuan data riset (Makarim et al., 2020). Riset dengan pendekatan kualitatif cenderung bersifat induktif, artinya terdapat proses eksplorasi berbagai temuan tidak harus disertai dengan hipotesis penelitian. Selain itu, penelitian jenis ini juga memiliki kekhasan pada ideografik, di mana temuan riset dialokasikan pada konteks waktu (sejarah) yang spesifik, sehingga tidak ada kebenaran yang bersifat mutlak (Yurisma \& Bahruddin, 2020). Penelitian ini difokuskan pada pengamatan perilaku berbusana dosen dan mahasiswa dalam mendalami makna busana yang menjadi cermin identitas untuk mendapatkan jawaban yang dicari.

Riset mengenai fesyen islami ini akan ditelusuri lebih lanjut menggunakan studi kasus, karena fenomena yang diteliti khususnya di kalangan dosen maupun mahasiswi di Kota Semarang melekat pada permasalahan penelitian terkait pandangan dan identitas mereka selaku muslimat. Selain itu, peneliti mengelaborasi fenomena tersebut dengan konteks keberadaan para akademisi menjalani keseharian mereka tanpa adanya tindak manipulasi terhadap perilakunya. Hal ini sepenuhnya telah memenuhi kaidah metode penelitian studi kasus, di mana peneliti akan meneluri proses sebagai jawaban atas pertanyaan "bagaimana?" hingga motif atau alasan yang mendasari untuk pertanyaan “mengapa?" (Prihatsanti, 2018).

Pengumpulan data dilakukan melalui wawancara mendalam dan ditopang oleh observasi. Narasumber yang memberikan penilaian dan pandangan mereka tentang gaya fesyen islami terdiri atas empat dosen dan empat mahasiswa dari beberapa perguruan tinggi umum di Kota Semarang. Perguruan tinggi umum dipilih karena motivasi dan identitas fesyen islami di lingkungan kampus lebih kompleks dan heterogen. Dinamika identitas fesyen islami di perguruan tinggi umum lebih menarik diamati karena terdapat banyak persinggungan agama dan budaya. Penelitian ini dilakukan dengan mewawancarai narasumber empat mahasiswa dan empat dosen dari Universitas Dian Nuswantoro dan Universitas Diponegoro Semarang. Sebelum melakukan wawancara terlebih dahulu diawali dengan melakukan studi pustaka pada minggu pertama dan kedua Juli 2020. Penelitian sendiri dilakukan pada Agustus sampai September 2020, 
kemudian dilanjutkan dengan evaluasi pada minggu ketiga dan keempat September 2020.

\section{Hasil dan Pembahasan}

Ciri dan sifat khas yang melekat pada sesuatu dan dapat membedakannya dengan yang lainnya disebut sebagai identitas. Konsep diri merupakan cara melihat secara keseluruhan mengenai gambar diri, meliputi persepsi seseorang tentang kediriannya, hal yang dirasakan, prinsip yang diyakini, dan beragam nilai yang berkaitan erat dengan dirinya. Identitas diperoleh dari berbagai ekspresi yang dapat dikenali oleh orang lain maupun merepresentasikan diri kita sendiri. Identitas dapat dimaknai pula melalui ragam latar belakang, seperti budaya, gender, profesi yang digeluti, asal negara, juga jenis pakaian yang sedang dikenakan seseorang (Lisdiyastuti, 2015). Identitas yang dimiliki manusia dapat diekspresikan dengan berbagai cara salah satu dengan busana atau pakaian.

Agama Islam dikenal sebagai agama yang sifatnya universal, karena cermin sebuah tindak ketundukan untuk menjalankan syariat serta sunah atau hadis dari Rasulullah. Hal ini juga sejalan dengan perintah Allah bahwa umat Islam disarankan untuk mengamalkan agamanya secara totalitas, sedapat mungkin berani menghindarkan diri dari segala larangan-Nya. Sayangnya, pada zaman modern ini banyak nilai ajaran Islam yang ditinggalkan. Hal tersebut bisa dilihat dalam keseharian umat muslim yang seringkali mengabaikan ajaran agama, salah satunya menutup aurat dan memakai hijab.

Menjadi seorang perempuan dalam ajaran Islam harus menjadi suatu kebanggaan yang patut disyukuri, karena bagian dari amanah Allah SWT kepada umat yang dikasihi-Nya (Aslati \& Silawati, 2018). Terdapat banyak aturan dalam Al-Qur'an, salah satunya adalah tentang cara berpakaian muslimat. Perempuan menjadi begitu menarik untuk ditelaah karena citra dan martabatnya diangkat dalam cerita Al-Qur'an (Triantoro, 2018). Al-Qur'an menyebut secara khusus dalam satu surat tentang perempuan, yaitu pada Q.S. An-Nisa' atau umumnya populer disebut pula sebagai An-Nisa' Al-Kubra (Hunawa, 2018). Tidak hanya itu, dalam Al-Qur'an tentang perempuan tidak hanya dituliskan berkaitan keagamaan, norma sosial, cara berpakaian, dan tata berkelakuan (Fauzi, 2016).

Dari sekian banyak pembahasan spesial tentang perempuan, salah satu hal penting untuk ditelaah lebih lanjut terkait aturan berpakaian seperti menutup aurat atau berhijab, yang dalam penafsirannya para ulama memiliki perbedaan pendapat. Ajaran tentang menutup aurat atau memakai hijab, diilhami dari Al-Qur'an dengan kutipan kalimat awal berbunyi "wanita yang beriman", bahwa tersirat penjelasan pentingnya menutup aurat bagi wanita muslim (Habibah, 2014). Sebaiknya dalam membahas ajaran menutup aurat atau berhijab, yang diutamakan adalah persoalan iman setiap individu, dalam hal ini adalah wanita. Sebab iman adalah dasar dari segala perintah Rasul untuk ditaati, termasuk di dalamnya ajaran cara berpakaian dan menutup aurat (Wijayanti, 2017). 
Busana dapat berfungsi sebagai alat komunikasi serta dapat menjadi sarana pencitraan sosial. Penggunaan busana juga sangat berpengaruh dalam kehidupan sosial seseorang, yaitu dapat menaikkan derajat sosial dan kemuliaan seseorang dalam kehidupan bermasyarakat. Terdapat fungsi komunikatif dalam busana yang dikenal sebagai komunikasi artifaktual yang memberikan kesan pada personalitas citra seseorang. Pandangan ini sejalan dengan pemikiran Thomas Carlyle, bahwa busana adalah perlambang dari jiwa (emblems of the soul) penggunanya. Maka fesyen selain dapat mengidentifikasi kesamaan nilai di dalam suatu kelompok juga dapat membedakan kelompok satu dengan lainnya (Rukiah, 2016)

Komunikasi artifaktual dapat diimplementasikan melalui busana juga dipandu oleh penataan beragam aspek, seperti pakaian, riasan wajah, aksesoris, kancing baju, bahkan sampai penataan dan dekorasi rumah. Hal ini dikarenakan busana menyiratkan pesan yang tidak disampaikan dengan kata-kata atau diklasifikasikan sebagai komunikasi nonverbal. Busana menjadikan setiap orang dapat mengekspresikan suasana hatinya ditandai dengan jenis pilihan warna, kemudian dipadu dengan motif yang melekat maupun model busana yang dipilih, sehingga cenderung masuk dalam kategori komunikasi nonverbal (Budi, 2014).

Saat ini fesyen islami menjadi salah satu tren busana yang sedang digemari, terutama di Indonesia. Perkembangan ini memberikan kesempatan bagi Indonesia untuk menjadikan negara ini sebagai salah satu pusat busana islami di dunia. Pusat busana islami ini menjadikan Indonesia sebagai acuan dalam perkembangan busana islami. Fenomena perkembangan busana islami di Indonesia dapat dijadikan tren yang diikuti perkembangannya, sebab konsumsi masyarakat dalam membeli komoditas busana muslim yang semakin banyak. Kota-kota besar di Pulau Jawa sangat menggambarkan bahwa industri busana muslim sedang berkembang (Istiani, 2015). Bentuk perkembangan busana islami didominasi oleh perkembangan hijab dan tata cara pemakaiannya.

Dalam berbusana islami wanita harus menutupi bagian kepala yang dikenal dengan istilah jilbab, hijab, dan kerudung. Terminologi istilah tersebut bagi masyarakat Indonesia masih sering ditukar-tukar dalam penamaan atau penyebutannya. Ada yang menyebutnya dengan disebutan jilbab, kadang disebut kerudung. Sampai saat ini penamaan atau penyebutanpun masih saling terjadi perbedaan pendapat antar individu (Asis, 2017). Mengenai makna tentang hijab setiap individu memiliki persepsi yang berbeda.

Hijab adalah satu keseluruhan kerudung dan semua yang dipakai dari atas sampai bawah, jadi tidak hanya kerudung saja (Reni Yesiana).

Hijab identik dengan busana muslimat, meski sebenarnya bukan muslimat saja yang memakai hijab (Yulikhah, 2016). Jika perempuan muslim memakai hijab artinya sebagai bentuk ketaatan terhadap ajaran Islam. Menurut Islam aurat kaum hawa adalah seluruh bagian tubuh, pengecualian pada dua bagian tubuh saja, yaitu bagian wajah serta 
telapak tangan perempuan saja yang diperkenankan untuk dilihat oleh orang lain, selain yang dibolehkan oleh agama. Sekarang ini terlihat banyak kaum hawa menggunakan hijab dengan mengikuti tren yang sedang ada seperti dipadukan dengan celana atau rok berbahan jeans atau berbahan karet yang ketat. Para ahli fikih sepakat menarik kesimpulan bersama bahwa aurat kaum hawa adalah keseluruuhan tubuh perempuan kecuali bagian muka serta telapak tangan. Di sisi lain, ada pula yang berpendapat bahwa bagian telapak kaki perempuan tidak diatur dalam aturan aurat yang harus ditutup, dengan kata lain dikecualikan. Menutup aurat memiliki tujuan untuk tidak mempertotonkan keindahan bentuk tubuh kaum hawa. Sekarang ini banyak yang beranggapan bahwa hijab merupakan gaya hidup seorang wanita muslim yang bersifat "kompromistis" nilai budaya yang dianggap islami dan nilai budaya cenderung lebih modern (Asis, 2017).

Memakai hijab dianjurkan karena sebagai bentuk untuk menutup aurat sesuai ajaran agama Islam. Sayangnya, pada masyarakat berkembang dengan sedemikian rupa. Sehingga masih ada yang belum memakai hijab dengan berbagai faktor dan alasan yang mendasari (Budiyanti, 2017) Pemahaman tentang ajaran Islam menjadi pembeda dalam hal pemakaian hijab. Reni mencontohkan suatu kasus yang kerap terjadi pada kalangan mahasiswa yang berdomisili di Kota Semarang.

llmu yang belum sampai kepada mereka (mahasiswa), jadi harus mengilmui dulu agar tahu bagaimana cara berhijab yang benar (Reni).

Penggunaan hijab awalnya bertujuan sebagai upaya seseorang menjalankan tugas dan identitas agama sebagai muslimat. Namun kini penggunaan hijab bergeser menjadi bagian dari gaya hidup yang melekat untuk menunjukkan identitas muslimat modern. Kalangan muslimat yang menjadikan hijab sebagai medium cerminan identitas diri agar masuk ke dalam berbagai sisi kehidupan sosial masyarakat.

Orang yang berhijab santun dan anggun (Christy).

Bicara tentang hijab berarti menutup aurat dengan sebaik-baiknya, menjaga pandangan, tidak memperlihatkan lekuk tubuh (Made).

Hijab bukan lagi hanya masalah ajaran agama. Ada berbagai alasan yang melatarbelakangi seseorang menggunakan hijab. Misalnya pertama, merasa terpanggil sampai akhirnya memakai hijab karena menyadari bahwa hijab adalah keharusan sebagai seorang muslimat. Kedua, memutuskan berhijab karena ada unsur paksaan dari lembaga atau instansi tertentu yang mewajibkan seorang wanita harus menggunakan hijab. Ketiga, didasarkan atas alasan psikologis, contohnya seseorang merasakan ketidaknyamanan untuk tidak menggunakan hijab karena mayoritas perempuan di lingkungannya menggunakan hijab. Keempat, merasa bahwa menggunakan hijab adalah tuntutan dari gaya hidup agar terlihat kekinian. Kelima, beberapa di antaranya memiliki unsur politis, yaitu guna memenuhi adanya tuntutan kelompok Islam tertentu yang 
cenderung mengedepankan busana muslim sebagai simbol agama Islam sebagai komoditas dagangan politik (Yulikhah,2016). Salah satu penyebab pemakaian hijab yaitu pengaruh lingkungan di mana seseorang itu berada atau tinggal. Sebab lainnya, seperti mulai sadar akan kewajiban dan mengikuti tren, juga bisa mempengaruhi pemakaian hijab.

Yang pertama bisa karena kesadaran kewajiban memakai hijab, mengikuti trend, dan bisa juga karena pengaruh teman (Fani).

Sebagai tanda sebagai seorang muslimat, dan tanda bahwa ia berusaha menjalankan kewajiban menutup aurat (Vanny).

Pada awalnya pemakaian hijab hanya sebatas untuk menunjukan identitas agama. Tapi sekarang ini seseorang juga memakai hijab alat untuk merepresentasikan identitas diri dalam kehidupan sosial. Kesimpulan yang bisa diambil dalam hal berhijab sekarang ini yaitu, seorang wanita berhijab tidak hanya mematuhi ajaran agama tapi juga untuk memenuhi kebutuhan gaya hidup sebagai seorang muslim. Peran hijaber yang ikut mempromosikan hijab menjadi salah satu alasan mengapa hijab di masa sekarang dianggap tren baru. Dulu hijab dianggap sebagai pakaian yang kuno dan tidak modis, tetapi sekarang hal tersebut mulai hilang.

Dulu banyak persepsi hijab tidak bisa fashionable (Vanny).

Peran muslimat hijaber sangat mempengaruhi, dulu berpikiran hijab itu-itu saja tapi dengan adanya kreatifitas, berdampak semakin banyak orang pakai hijab. Biasanya dimulai melihat di medsos, kemudian mempengaruhi keputusan pembelian dalam pemilihan hijab (Reni).

Berbicara tentang dialetika, Berger dan Luckmann berpendapat bahwa dialetika antar individu terjadi dalam konstruksi sosial. Hal ini berkesinambungan berproses di masyarakat secara simultan menciptakan sebuah pengetahuan bagi setiap orang. Interaksi antar manusia akan terus terjadi dalam lingkungan sosial dan menumbuhkan nilai sosial yang dapat terjadi dalam kelompok tertentu, dengan menciptakan tanda atau simbol ataupun melalui lisan, berjabat tangan, bahasa isyarat, bahkan dengan menggunakan komukasi jarak jauh (Marta \& Rieuwpassa, 2018).

Gaya fesyen hijab di Indonesia sudah mengalami pergeseran makna. Dulu hijab digunakan hanya untuk menutupi aurat, tetapi sekarang dianggap mode baru dan sedikit memudarkan makna yang ada pada hijab. Tetapi jika melihat perkembangan gaya busana muslimat beberapa tahun terakhir mengalami peningkatan, khususnya di Indonesia. Masyarakat termasuk di dalamnya desainer dan produsen pakaian semakin memiliki ketertarikan akan berbusana muslim dan semakin hari semakin meningkat. Makna utama hijab untuk menutup aurat telah tertutupi tujuan lain menggunakan hijab yaitu hijab sebagai fesyen (Istiani, 2015). Pengguna hijab fesyen pun banyak yang belum memahami mengenai hukuman menjadikan hijab yang keluar dari tujuan penutup aurat. 
Tidak tahu hukum, atau bisa juga belum mengerti esensinya mengenai hukum. Dampak negatif adanya hal tersebut adalah tidak bisa menutup aurat, maka lahirlah istilah jilboobs, memakai hijab tapi masih kelihatan jelas bentuk payudaranya (Vanny).

Mengikuti tren yang sedang berkembang juga jadi motivasi penggunaan hijab. Hal tersebut ditunjukkan oleh para narasumber dalam melihat gaya fesyen mahasiswa di kampus. Terdapat dinamika mahasiswa menggunakan hijab, mulai yang syar'ai hingga yang sekadar mengikuti tren tetapi belum bisa menutup aurat dengan baik.

Ada yang syar'i dan ada yang cuma menutup rambut (Made).

Biasanya hanya untuk fesyen saja yang sedang berkembang. Masih bersifat gayagayaan, belum bisa bersifat istiqomah (Christy).

Secara bertahap, mulai dari SD hanya memakai hijab biasa-biasa saja, kemudian kuliah lebih kreatif dalam mengkreasikan hijab. Tidak menutup aurat tidak masalah karena masih belajar (Vanny).

Hijab sudah menjadi salah satu kebutuhan untuk menunjang penampilan wanita, tidak hanya menjadi suatu kewajiban dalam menjalankan ajaran agama Islam. Setiap produsen menciptakan beragam inovasi baru untuk menciptakan keunggulan produk meraka dan bangsa pasar yang dituju adalah adalah perempuan muslim. Para produsen beranggapan bahwa belanja hijab di era sekarang ini sudah menjadi kebutuhan untuk memenuhi gaya hidup.

Perkembangannya semakin pesat, bentuk bermacam-macam, dan cara penjualannya juga bemacam-macam (Made).

Fesyen muslimat sekarang ini terjadi perubahan, dari gaya tradisional atau kuno menjadi modern atau kekinian mengikuti tren kaum muda. Di pasaran terlihat produkproduk hijab yang memiliki ragam bentuk dan warna, termasuk di Kota Semarang. Hal itu menggambarkan muslimat Indonesia membuka diri terhadap fesyen modern, sebagai bentuk toleransi serta keterbukaan terhadap keberagaman. Dalam industri busana muslim terdapat nilai budaya masyarakat muslim yang memiliki kreativitas dan cinta damai di mata dunia. Dunia fesyen muslim juga mengalami perubahan yang sangat cepat dan signifikan. Jika kita lihat ke belakang, model fesyen muslim zaman dulu masih sangat tradisional tetapi sekarang ini sudah sangat beragam dan modis.

Gaya berbusana muslim mengalami perubahan yang signifikan di Indonesia. Aturan atau ajaran dalam berpakaian menurut Islam dengan mudah disesuaikan di Indonesia, mengikuti budaya masing-masing. Ajaran menutup aurat bagi kaum muslimat di Indonesia justru hadir dengan nuansa yang berbeda lengkap dengan atribut lainnya, membuatnya lebih unik dibandingkan dengan di Arab yang merupakan pusat peradaban Islam. Indonesia menarik perhatian dunia dalam mode berbusana muslim, 
sehingga terdapat wacana pencanangan Indonesia sebagai pusat mode busana muslim dunia pada tahun 2020 dalam pada Indonesia Fashion Week 2013 lalu.

Saya memberikan apresiasi setinggi-tingginya pada mereka yang komitmen taat menjalankan perintah agama. Mereka berusaha untuk taat dan tunduk pada syariat sesuai dengan Allah SWT sampaikan dalam Al-A'raf, Al-Hasyr, An-Nur. (Made)

Orang yang berhijab memiliki jiwa yang santun dan anggun (Kristiantika).

Perkembangan industri fesyen muslim tidak hanya dirasakan masyarakat sebagai pengguna, melainkan juga pengusaha dan praktisi di bidang busana. Perkembangan fesyen muslim akan membantu Indonsia dalam memasuki perdagangan bebas di Asia. Globalisasi di bidang perekonomian mengharuskan adanya penghapusan berbagai batasan yang cenderung menghambat arus permodalan, distribusi barang maupun jasa, sehingga Indonesia harusnya lebih siap memasuki globalisasi secara perekonomian (So'imah, 2012).

Peran muslimat fashionable dapat bermanfaat untuk mengedukasi pemakaian hijab bagi masyarakat (Christy).

Gaya berbusana sangat penting untuk merepresentasikan identitas seseorang, tidak terkecuali mahasiswa. Gaya fesyen islami yang berkembang di kalangan mahasiswa di Kota Semarang sangat beragam dan dipengaruhi oleh beberapa faktor. Penulis memberikan sebuah gambaran berdasarkan wawancara dengan beberapa mahasiswa di Kota Semarang. Para mahasiswa mengakui, kebanyakan dari mereka memakai hijab bukan sekadar untuk memenuhi kewajiban agama, tetapi lebih dari hal itu sebagai kebutuhan. Menurut mereka, keputusan memakai hijab merupakan keputusan pribadi. Beberapa dari mereka memberikan argumen bahwa hijab dan busana islami lainnya, dapat menjadikan mereka lebih berhati-hati dalam berperilaku.

Mereka berpendapat, gaya fesyen islami membantu mereka menemukan kembali identitas keislamannya. Hijab yang merupakan fesyen islami dapat menjadikan mereka sebagai perempuan yang bertanggung jawab dan berhati-hati dalam bersikap dan berperilaku. Misalnya, pengalaman pribadi narasumber yang pernah memakai hijab kurang menutup aurat dengan hijab yang menutup aurat.

Ketika memakain hijab syar'i harus mengontrol diri, dan harus berhati-hati dalam berperilaku dan bertingkah (Vanny).

Menutup aurat dengan berhijab merupakan bentuk ketaatan dalam menjalankan ajaran agama Islam. Namun seiring berkembangnya fesyen modern terdapat unsur mengikuti perkembangan mode yang disebut dengan hijab kekinian, lengkap dengan pernak-pernik untuk menjadikan hijab terlihat lebih menarik. Tren hijab modern ini mempengaruhi cara pandang dalam penggunaan hijab pada kalangan sivitas akademika yang terbagi dalam beberapa kelompok. Kelombok yang sangat jelas terlihat adalah 
mahasiswi yang beranggapan bahwa berhijab adalah sebuah bentuk sikap taat atas perintah agama (hijab syar'i). Kelompok lainnya memiliki cara pandang berbeda, bahwa hijab dinilai berkaitan dengan tren dan gaya hidup wanita muslim, dengan bahasa kekinian disebut hijaber.

Proses pembentukan makna dalam berhujab merupakan sebuah dialektis terhadap individu itu sendiri. Pada kalangan sebebritas misalnya, ada fenomena lain seperti Rina Nose yang berani memutuskan untuk melepas hijab, menjadi sebuah contoh suasana pergolakan batinnya. Pada awalnya Rina Nose seorang muslimat yang tidak menggunakan hijab, setelah itu ia berhijab, tapi pada akhirnya kembali menanggalkan hijabnya. Fenomena ini merupakan contoh sebuah dialektis seseorang dalam memberi makna terhadap realitas sosial yang sedang terjadi.

Pada saat seorang wanita memutuskan untuk berhijab, merupakan sebuah proses pengenalan, setelah itu masuk dalam tahap penyesuaian, dan akhirnya menggunakan hijab karena merasakan keterpanggilan. Proses ini disebut sebagai Beruf atau calling oleh Max Weber. Yaitu saat seseorang memutuskan untuk menggunakan hijab karena merasa ada sebuah panggilan ilahiah. Kehidupan pada kalangan sivitas akademika terkait penggunaan hijab, mereka mencoba mencoba menemukan dan mengenali kelompok mana yang sesuai dengan gaya mereka berhijab. Terjadi suatu fenomena yang mencengangkan, ketika para hijaber menganggap dengan menutup auratnya adalah sebuah ibadah dan sudah sesuai dengan syariat dan memandang diri mereka juga menyesuaiakan dengan gaya mode terbaru dan terlihat kekinian (Asis, 2017). Meskipun demikian mereka tidak menampik kalau ada di antara mereka memakai hijab hanya sebagai busana untuk gaya fesyen saja tanpa berpengaruh terhadap kehidupan mereka.

Dengan kehadiran para hijaber membuat hijab semakin tersosialisasi. Semakin banyak orang akan berhijab. Perubahan yang dialami banyak sekali, mulai dari kehidupan yang lebih baik dan karir yang semakin naik (Made).

Transformasi di era globalisasi sekarang ini juga terjadi dalam hal berhijab, yang penggunaannya tidak hanya berdasarkan pada nilai-nilai agama namun juga mengikuti mode agar memiliki kesan gaul atau kekinian. Globalisasi mendorong terciptanya gelombang masyarakat berisiko. Karena era sekarang ini banyak wanita mengambil keputusan berhijab tidak semata-mata sebagai panggilan Allah. Tidak sedikit mereka memenuhi keinginan mengikuti model hijab yang telah menjadi tren dengan model kekinian ciri khas motif dan hiasannya (Asis, 2017 ).

Ekspresi identitas dapat melalui berbagai macam cara salah satunya busana. Gaya fesyen mahasiswa jika ditelusuri lebih mendalam dapat mencerminkan identitas mereka sebagai bagian dari komunitas sosial, tidak terkecuali identitas keislaman mereka. Fesyen dianggap dapat merepresentasikan identitas bagi seseorang. Gaya busana yang dipakai oleh seseorang merupakan hasil ekspresi yang ingin ditimbulkan oleh seseorang. Maka busana menjadi penting bagi seseorang terutama perempuan. Kaum 
perempuan sering menuangkan ekspresi dirinya lewat cara berbusana, sehingga fesyen menjadi penting bagi mereka terutama remaja atau usia menjelang dewasa.

Mahasiswi Udinus sangat fashionable, trendi, modern dan dinamis dengan warna yang cerah (Made).

Gaya fesyen hijab sudah baik, tetapi masih ada yang terbawa pergaulan sehingga hijab hanya menjadi fesyen dan kurang menutup aurat (Christy).

Dinamika pemikiran dalam perguruan tinggi yang kompleks dapat menimbulkan cara pandang berbeda yang cukup berisiko untuk menempatkan busana sebagai sebuah jati diri atau identitas. Cara pandang sebagian orang, busana adalah jati diri atau identitas diri, sebagiannya lagi beranggapan bahwa busana tidak lebih dari penutup tubuh saja yang tak perlu dikemas "selaras" untuk dikenakan ketika berada di perguruan tinggi. Sederhananya, perguruan tinggi adalah tempat terjadinya perebutan identitas citra terjadi sedemikian rupa, berikutnya juga menjadi ruang bagi perebutan dominasi di antara berbagai jenis mode (Lestari, 2014).

Suatu fenomena umum berhijab sekarang sudah menjadi suatu kebutuhan bagi perempuan muslim, termasuk para mahasiswa. Mulanya hanya ikut-ikutan teman atau melihat tren gaya fesyen yang berkembang. Namun dalam perkembangannya, diharapkan mereka memakai hijab sebagai kebutuhan untuk menjaga kehormatan diri dan dapat melaksanakan perintah Allah SWT untuk menutup aurat.

\section{Simpulan}

Setiap individu memiliki identitas yang melekat dalam pribadinya masing-masing. Identitas seseorang dapat terbentuk karena adanya interaksi sosial dengan orang lain yang berada di sekitarnya. Bagi perempuan fesyen sangat penting untuk merepresentasikan identitasnya, sehingga banyak perempuan memandang fesyen sebagai bagian penting pada dirinya. Identitas dapat diwujudkan salah satunya melalui busana atau pakaian, karena sebuah pakaian atau busana berkaitan dengan nilai atau pesan yang ingin disampaikan bagi pemakai atau penata busananya. Salah satu peran fesyen sebagai identitas terlihat dengan berkembangkan fesyen islami. Salah satu fenomena yang terlihat yaitu pada kalangan sivitas akademika, terutama mahasiswa dalam pemakaian hijab. Penelitian ini menemukan dua kelompok pengguna fesyen islami, yaitu mereka yang memakai hijab untuk kebutuhan menurut aurat seperti diajarkan dalam Islam dan mereka yang sekadar mengikuti tren gaya fesyen yang berkembang.

\section{Referensi}

Asis, P.H. (2017). Makna berhijab bagi muslimat: sebuah persepsi mahasiswi fisip universitas muhammadiyah kendari. Jurnal Dakwah Tabliq, 18(2), 92-106. https://doi.org/https://doi.org/10.24252/jdt.v18i2.4703

Aslati \& Silawati. (2018). Fenomena Eksplorasi Perempuan Oleh Media. Jurnal Dakwah Risalah, 29, 133-142. https://doi.org/10.24014/jdr.v29i2.6389 
Budiyamti, S. (2017). Faktor-faktor yang mempengaruhi Pemakaian Jilbab di Kalangan Mahasiswi Universitas Swadaya Gunung Jati Kota Cirebon. Al-Tadzkiyyah: Jurnal Pendidikan Islam, 8(Ii), 201-212. https://doi.org/10.24042/atjpi.v8i2.2125

Dewi, M. T., \& Puspitasari, C. (2018). Penerapan Konsep Syar'i Modern Pada Desain Busana Pengantin Muslimat. Atrat: Jurnal Seni Rupa, 6(3), 235-241. https://doi.org/https://jurnal.isbi.ac.id/index.php/atrat/article/view/593/431

Fauzi, A. (2016). Pakaian Wanita Muslimat Dalam Perspektif Hukum Islam. Jurnal Ekonomi Syariah, $1(1)$, 41-58. http://ejournal.alqolam.ac.id/index.php/iqtishodia/article/download/56/61

Febriani, S. F., \& Purwanto, N. (2019). Pengaruh Shopping Lifestyle Dan Fesyen Involvement Terhadap Impulse Buying Pada Konsumen Hijab Butik Rabbani Jombang. JMD: Jurnal Riset Manajemen \& Bisnis Dewantara, 2(2), 53-62. https://doi.org/10.26533/jmd.v2i2.372

Habibah, S. (2014). Sopan Santun Berpakaian Dalam Islam. Jurnal Pesona Dasar, 2(3). https://doi.org/http://www.jurnal.unsyiah.ac.id/PEAR/article/viewFile/7500/6172

Hayati, A. R., Yasir, Y., \& Salam, N. E. (2020). Fenomena Komunikasi Muslimat Bercadar Melalui Media Sosial Di Pekanbaru. Jurnal Dakwah Risalah, 31(1), 85. https://doi.org/10.24014/jdr.v31i1.9949

Hunawa, R. (2018). Kedudukan suami-istri (kajian surah an- nisa' [4]: 34). JURNAL POTRET --Journal Penelitian Dan Pemikiran Islam, 2(1). https://doi.org/http://dx.doi.org/10.30984/pp.v22i1.758

Ilyas, M. (2016). Memaknai Fesyen dalam Hukum Islam. Al Daulah: Jurnal Hukum Pidana Dan Ketatanegaraan, 5(1), 133-143. https://doi.org/https://doi.org/10.24252/ad.v5i1.1446

Istiani, A. N. (2015). Konstruksi Makna Hijab Fesyen Bagi Moslem Fesyen Blogger. Jurnal Kajian Komunikasi, 3(1), 48-55. https://doi.org/10.24198/jkk.vol3n1.6

Latifah, K. (2014). Hijabers di Era Informasi (Studi Information Sharing dan Gaya Hidup Hijabers di Komunitas Hijabers Surabaya). Jurnal Unair, 3(1). https://doi.org/https://journal.unair.ac.id/mobile/LN@hijabers-di-era-informasiarticle-7501-media-136-category-8.html.

Lestari, S. B. (2014). Fesyen sebagai Komunikasi Identitas Sosial di Kalangan Mahasiswa. Ragam Jurnal Pengembangan Humaniora, 14(3), 225-238. https://doi.org/https://jurnal.polines.ac.id/index.php/ragam/article/view/514/439

Lisdiyastuti, E. (2015). Jilbab sebagai Identitas diri Lingkungan Sekolah (Studi Denomenologi tentang Alasan dan Dampak Pemakaian Jilbab oleh Siswa Kelas XI SMA Negeri 3 Sragen). Sosialitas: Jurnal Ilmiah Pendidikan SosiologiAntropologi, 53(1), 1-13. https://doi.org/https://eprints.uns.ac.id/id/eprint/23781

Makarim, N. H., Dimyati, D., \& Kurniullah, A. Z. (2020). THE USE OF INSTAGRAM ACCOUNT IN CONSTRUCTING THE CONCEPT OF BEAUTY: A CASE ON “UNPAD GEULIS". ASPIRATION Journal, 1(1), 73-98.

Marta, R. F., \& Rieuwpassa, J. S. (2018). Identifikasi Nilai Kemajemukan Indonesia Sebagai Identitas Bangsa dalam Iklan Mixagrip Versi Keragaman Budaya. Jurnal Kajian Komunikasi, 6(1), 37. https://doi.org/10.24198/jkk.v6i1.15416

Nisa, K \& Rudianto. (2017). Trend Fesyen Hijab Terhadap Konsep Diri Hijabers Komunitas Hijab Medan. Jurnal Interaksi, 1(1), 105-117. https://doi.org/https://doi.org/10.30596/interaksi.v1i1.882

Prihatsanti, U., Suryanto, S., \& Hendriani, W. (2018). Menggunakan Studi Kasus 
sebagai Metode Ilmiah dalam Psikologi. Buletin Psikologi, 26(2), 126. https://doi.org/10.22146/buletinpsikologi.38895

Ramadhini, E. (2017). Jilbab sebagai Representasi Simbolik Mahasiswi Muslim di Universitas Indonesia. MASYARAKAT: Jurnal Sosiologi, 22(1). https://doi.org/https://doi/org/10.7454/mjs.v22i1.6835

Rukiah, Y. (2016). Fesyen sebagai Gaya Hidup Masyarakat Kota Studi Kasus: Gaya Hijabers Community. Dimensi DKV, 1, 45-59. https://doi.org/https://www.trijurnal.lemlit.trisakti.ac.id/index.php/seni/article/view $/ 1358$

So'imah, N. (2012). Strategi Pemasaran Produk Busana Muslim "Galeri Dita" Pada Era Globalisasi. Fesyen and Fesyen Education Journal, 1(1), 20-23. https://doi.org/https://doi.org/10.15294/ffej.v1i1.201

Triantoro, D. A. (2018). Pandangan Al-Qur'an Tentang Perempuan: Kritik Terhadap Tuduhan Kaum Feminisme. Cakrawala: Jurnal Studi Islam, 13(1), 74. https://doi.org/10.31603/cakrawala.v13i1.2057

Wijayanti, R. (2017). Jilbab Sebagai Etika Busana Muslimat dalam Perspektif Al- Qur' an. Cakrawala: Jurnal Studi Islam, XII(2), 151-170. https://doi.org/https://doi.org/10.31603/cakrawala.v12i2.1842

Yulikhah, S. (2016). Jilbab Antara Kesalehan dan Fenomena Sosial. Jurnal Ilmu Dakwah, 36(1), 96-117. https://doi.org/DOI: http://dx.doi.org/10.21580/jid.36.1.1627

Yurisma, D. Y., \& Bahruddin, M. (2020). Pemaknaan Simbol Reog Ponorogo Dalam Tradisi Jawa: Sebuah Kajian Kritis. Bricolage : Jurnal Magister Ilmu Komunikasi, 6(01), 101. https://doi.org/10.30813/bricolage.v6i01.2070 